\title{
MATEMATICKÉ MODELY PRO ANALYTICKÝ VÝPOČET ENERGOPILOT
}

\author{
MATHEMATICAL MODELS FOR ANALYTICAL CALCULATION OF \\ ENERGYPILES
}

\author{
Jakub Oravec ${ }^{1}$, Ondřej Šikula ${ }^{1}$ \\ ${ }^{1}$ Vysoké učení technické v Brně, Fakulta stavební, Veveři 331/95, 60200 Brno, Česká republika
}

\begin{abstract}
Abstrakt
Súčasným trendom je znižovanie energetickej náročnosti budov využívaním alternatívnych zdrojov vykurovania a chladenia. Jedným z najperspektívnejších a zdrojov vykurovania a chladenia je využitie energie zeme pomocou tepelne aktivovaných základových pilót budovy, takzvaných energetických pilót. Príspevok sa zaoberá prehl'adom a porovnaním analytických modelov energetických pilót. Jednotlivé analytické modely sú porovnávané (kategorizované) z hl'adiska ich fyzickej náročnosti, výpočtovej náročnosti a tým aj využitel’nosti pre účely optimalizácie energetických pilót alebo hodnotenia dlhodobej energetickej efektívnosti pol’a energetických pilót. Vybrané matematické modely boli algoritmizované a získané výsledky boli porovnané s robustnejším numerickým riešením modelovaným pomocou softvéru CalA 4.
\end{abstract}

\section{Klíčová slova}

Epilota, g-funkcia, tepelný odpor, numerický model, analytický model

\begin{abstract}
A current trend is to reduce the energy performance of buildings by using alternative sources for heating and cooling. One of the most promising, and so far unprecedented sources of heating and cooling, is the use of energy from the earth using the thermally-activated foundation piles of a building, the so-called energy piles. The paper deals with an overview and comparison of computer-aided analytical models of energy piles. The individual analytical models are compared (categorized) from the point of view of their physical complexity, computational costs, and thus their usability for the purpose of optimizing energy-pile equipment or assessing the long-term energy efficiency of an energy pile field. Selected mathematical models were algorithmized, and the results obtained were compared with a more robust numerical solution performed using CalA 4 software.
\end{abstract}

\section{Key words}

Epile, g-function, thermal ressistance, numerical model, analytical model

\section{1 ÚVOD}

Epilota - tepelne aktivovaná pilota - je vertikálna základová konštrukcia v ktorej je umiestnený zemný výmenník tepla pomocou ktorého dochádza k odoberaniu (predávaniu) tepla medzi zeminou a teplonosnou látkou. Hlavnou výhodou je využitie geotermálnej energie, ktorá patrí medzi obnovitel'né zdroje tepla a oproti často používaným geotermálnym vrtom je ich využitie cenovo efektívne u budov, kde sú nutné pilotové základy. Obecne existujú dva spôsoby modelovania tepelných dejov prebiehajúcich v epilote - pomocou analytických modelov a pomocou numerických modelov. Analytické modely obsahujú viacero zjednodušení vd’aka čomu sa výrazne znižuje ich výpočtová náročnost'. Oproti tomu numerické modely dokážu pomerne presne simulovat' tepelné deje odohrávajúce sa v pilote a okolitej zemine ale tým pádom výrazne stúpa ich výpočtová náročnost'. Väčšina doteraz realizovaného výskumu sa zaoberá vrtmi ale ovel'a menej sa ich zaoberá tepelne aktivovanými pilotami. Ciel'om tohto článku bolo porovnat' vybrané analytické modely, pôvodne vyvinuté pre modelovanie vrtov, s numerickým riešením a určit', či je možné ich efektívne využívat' na modelovanie epilot. 


\section{ANALYTICKÉ MODELY}

Teoretický základ pre väčšinu konvenčných analytických modelov výchádza z Kelvin's theory of heat sources, Laplace transform method a Duhamel's theorem [1], [2]. Pri modelovaní epilot je obecne prenos tepla modelovaný v 2 oblastiach - v zemine a v pilote, ktoré sú zjednodušene považované za homogénne médium. Všetky modely využívajú zjednodušujúce predpoklady, medzi najbežnejšie patria:

- $\quad$ zemina je považovaná za nekonečnú alebo polo nekonečnú,

- jednotná počiatočná konštantná teplota,

- okrajová podmienka pre stenu piloty alebo potrubia je konštantný tepelný tok alebo konštantná teplota,

- zemina je považovaná za materiál s ekvivalentnou tepelnou vodivost'ou.

Hl'adanou veličinou pri modelovaní týchto tepelných dejov je tepelný tok q $[\mathrm{W} / \mathrm{m}]$ medzi teplonosnou látkou a zeminou ako funkcia času pri určitom teplotnom rozdiely medzi teplonosnou látkou a zeminou a je závislý na celkovom tepelnom odpore medzi nimi R(t) [m.K/W].

$$
q=\frac{T_{f}(t)-T_{0}}{R(t)}=\frac{T_{f}(t)-T_{0}}{R_{p}+G(x, t)}
$$

Stredná teplota teplonosnej látky a teplota zeminy sú známe veličiny, analytické modely sa zaoberajú hl’adaním vzt'ahov na určenie celkového tepelného odporu $\mathrm{R}(\mathrm{t})$. Celkový tepelný odpor býva v analytických modeloch rozdelený na 2 zložky - časovo závislú a časovo nezávislú. Časovo závislá zložka býva označovaná ako G-funkcia - G(x,t) - je teplotná odozva zeminy vzhl'adom na jednotkovú zmenu tepelného toku. G-funkcia popisuje tepelné deje odohrávajúce sa v zemine mimo piloty. Časovo nezávislá zložka celkového tepelného odporu - Rp - popisuje tepelné deje odohrávajúce sa v samotnej pilote a vyjadruje, že nestacionárne vedenie tepla v pilote sa zanedbáva. Je to teda tepelný odpor medzi cirkulujúcou teplonosnou látkou a vonkajšou stenou piloty [3].

\section{TEPELNÝ ODPOR ENERGOPILOTY}

Základným predpokladom pre zist’ovanie tepelného odporu piloty Rp je, že tepelné procesy v pilote sú v ustálenom stave. Tento stav je definovaný ako (rp [m] je polomer piloty) [3] :

$$
\mathrm{t}>5 \cdot\left(\mathrm{r}_{\mathrm{p}}^{2} / \mathrm{a}_{\mathrm{p}}\right)
$$

$\mathrm{V}$ čase $\mathrm{t}$ [s] je teda možné považovat' tepelný tok v pilote za ustálený a teplotný rozdiel medzi teplonosnou látkou a stenou piloty je konštantný. Modely pre Rp a tým pádom aj pre G-funkcie sú použitel’né len pri doržaní tohto kritéria. Tepelný odpor piloty Rp závisí hlavne od konfigurácie potrubia a tepelných vlastností výplňových materiálov piloty a okolitej pôdy. Tento lokálny tepelný proces má tri zložky:

- Rf tepelný odpor pri konvekčnom prestupe tepla medzi cirkulujúcou tekutinou a vnútorným povrchom rúrky výmenníku;

- $\quad$ Rpw je tepelný odpor pri kondukčnom prenose tepla cez stenu rúrky výmenníku;

- Rc je tepelný odpor pri kondukčnom prenose tepla cez výplňový materiál.

Celkový tepelný odpor môže byt' definovaný ako súčet týchto troch zložiek. Modely na výpočet Rp môžeme rozdelit' na empirické a teoretické. Empirické modely sa široko použivajú kvôli ich jednoduchosti a boli využité aj v našom porovnaní. Použitý empirický $1 \mathrm{D}$ model zjednodušuje reálne kruhové potrubie vinuté $\mathrm{v}$ tvare U na jedno potrubie s ekvivalentným priemerom. Tento zjednodušuje dvojrozmernú geometrickú oblast' na koncentrickú prstencovú oblast', vd’aka čomu sa komplikovaný mnohorozmerný problém obmedzuje na jednoduchý jednorozmerný [4].

$$
\mathrm{R}_{\mathrm{p}}=\frac{1}{2 \pi \lambda_{\mathrm{p}}} \ln \left(\frac{\mathrm{r}_{\mathrm{p}}}{\mathrm{r}_{\text {pipe }}} \sqrt{\frac{\mathrm{r}_{\text {pipe }}}{\mathrm{D}}}\right)
$$

\section{VÝPOČET G-FUNKCIE}

Modely pre výpočet G-funkcie vychádzajú z teoretických základov, ktoré navrhol Ingersoll [1]. V svojej práci prezentoval Infinite line source model, ktorý umožňuje teplotné pole v zemi zapísat' ako funkciu závislú od času 
a polomeru okolo líniového zdroja pri konštantnom tepelnom toku v rovine kolmej na verikálnu os piloty v nekonečnej pevnej látke. Tento model bol vyvinutý pre výpočet vrtov, ktoré majú polomer zvyčajne niekol'ko centimetrov a v porovnaní s jeho dížkou je polomer vel'mi malý. Tento vel'mi tenký vrt teda možno považovat' za líniu nekonečnej dížky bez objemu, ktorý odovzdáva (odoberá) teplo do (alebo z) okolitej pôdy.

$$
G(r, t)=\frac{1}{4 \pi \lambda_{s}} \int_{0}^{\infty} r_{p}^{2} / 4 a_{s} t \frac{\exp (-u)}{u} d u=\frac{1}{4 \pi \lambda_{s}} E_{1}\left(\frac{r_{p}^{2}}{4 a_{s} t}\right)
$$

Exponencionálny integrál E1 môže môže byt' pre vel'ké hodnoty parametru (at/r2), kde a [m2/s] je súčinitel' teplotnej vodivosti, zjednodušený na:

$$
\mathrm{E}_{1}\left(\frac{\mathrm{r}_{\mathrm{p}}^{2}}{4 \mathrm{a}_{\mathrm{s}} \mathrm{t}}\right)=\ln \left(\frac{4 \mathrm{a}_{\mathrm{s}} \mathrm{t}}{\mathrm{r}_{\mathrm{p}}^{2}}\right)-\gamma \quad \frac{a_{s} t}{r_{p}^{2}} \geq 5
$$

Infinite line source model sa považuje za zjednodušenie Cylindrical source model (Obr. 1), v ktorom je do úvahy braný aj radiálny rozmer piloty. Používané sú rovnaké vstupné parametre ako u Infinite line source model. Cylindrical source model považuje prenos tepla mimo piloty za vedenie tepla v nekonečnom priestore vnútorne ohraničenom stenou piloty, na ktorú môže byt' použitá okrajová podmienka konštantného tepelného toku alebo teploty[1]. Riešenie problému popisuje rovnica:

$$
G(r, t)=\frac{1}{4 \pi \lambda_{s}} \int_{0}^{\infty}\left(e^{-a_{s} u^{2} t}-1\right) \frac{J_{0}\left(u r_{p}\right) Y_{1}\left(u r_{p}\right)-Y_{0}\left(u r_{p}\right) J_{1}\left(u r_{p}\right)}{u^{2}\left[J_{1}^{2}\left(u_{p}\right)+Y_{1}^{2}\left(u r_{p}\right)\right]} d u
$$

Symboly J0,J1,Y0,Y1 v rovnici predstavujú Besselove funkcie prvého a druhého rádu. Rovnica môže byt' pre vel'ké hodnoty parametru (at/r2) zjednodušená na:

$$
G(r, t)=\frac{1}{4 \pi \lambda_{s}}\left[\ln \left(\frac{4 a_{s} t}{r_{p}^{2}}\right)-\gamma+\frac{r_{p}^{2}}{2 a_{s} t}\left(\ln \left(\frac{4 a_{s} t}{r_{p}^{2}}\right)-\gamma+1\right)\right]
$$

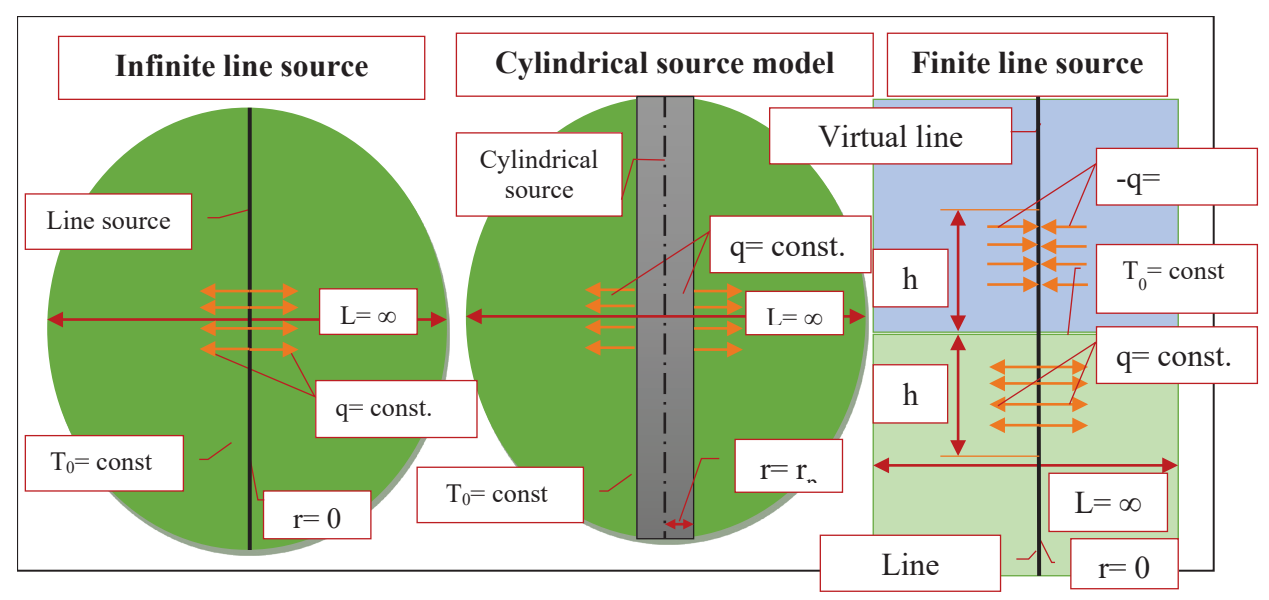

Obr. 1 Okrajové podmienky analytických modelov.

Kvôli využitiu predpokladu liniového zdroja je vzorec nevhodný pre malé časové kroky, pretože tento predpoklad môže spočiatku oddialit' teplotnú odozvu na stene vrtu. S relatívnou chybou menšou ako $10 \%$ medzi týmito dvoma modelmi môžu byt’ použité pri časovom kroku [3]:

$$
t \geq \frac{5 r_{p}^{2}}{a_{s}}
$$

A s relatívnou chybou menšou ako $2 \%$ pri časovom kroku [3]:

$$
t \geq \frac{20 r_{p}^{2}}{a_{s}}
$$

Dodržanie časového kroku s minimálnou hodnotou podl'a rovnice (10) sa vyžaduje, pri použití ktorejkol'vek z týchto G-funkcií v spojení s ktorýmkol’vek z modelov pre Rb. 
Rovnice nemožno použit' pre výpočty na vel’mi dlhé obdobie blížiacemu sa k hodnote [3]:

$$
t=\frac{H^{2}}{4 a_{s}}
$$

Toto obmedzenie vzniká z dôvodu zanedbania vplyvu povrchu zeme. To je spoločná nevýhoda všetkých modelov, ktoré predpokladajú, že pôda je nekonečným médiom.

Ďalším možným riešením, ktoré berie do úvahy teplotu na povrchu zeminy je Finite line source model [5]. Zemina je braná ako homogénne polo-nekonečné médium ktoré má počiatočnú jednotnú teplotu a jeho termofyzikálne vlastnosti sa nemenia so zmenou teploty. Hranica média, predstavujúca povrch zeminy si udržuje konštantnú teplota počas celého výpočtu.

Model využíva predpoklady Line source modelu a teda radiálny rozmer piloty je zanedbaný. Povrch zeme sa považuje za odrazovú rovinu a existuje zrkadlová obrazová línia chladičov (heat sinks). Symetrické rozdelenie líniového zdroja a chladičov môže udržiavat' teplotu povrchu zeme na konštantnej hodnote. Ako reprezentatívna teplota pre celú pilotu môže byt' zvolená teplota v strede steny piloty, ktorá dosahuje ustálený stav v čase blížiacom sa k nekonečnu. Pre praktické aplikácie definujeme nominálny ustálený stav v čase kedy dosiahneme určitý zvolený limit, v tomto prípade 98 \% ustáleného stavu. Pomocou linárne regresie môžme aproximovat’ Fourrierovo kritérium pre tento stav ako [5]:

$$
F o_{s}=3,8 \cdot \frac{r_{p}}{H}+0,29 \quad 0,001 \leq \frac{r_{p}}{H} \leq 0,7
$$

Ak sa čas blíži k nekonečnu je možné riešenie problému redukovat' na [5]:

$$
G(r)=\frac{1}{4 \pi \lambda_{s}} \ln \left[\frac{\sqrt{(H-z)^{2}+\rho^{2}}+H-z}{\sqrt{(H+z)^{2}+\rho^{2}}+H+z} \cdot \frac{2 z^{2}+2 z \sqrt{\rho^{2}+z^{2}}+\rho^{2}}{\rho^{2}}\right.
$$

V prípade, ked' je polomer piloty rb v porovnaní s jej híbkou $H[\mathrm{~m}]$ ovel'a menší $(\mathrm{rb} / \mathrm{H}<<1)$, je možné vzt'ah v ustálenom stave v strede steny vrtu zjednodušit' na [5]:

$$
G(r)=\frac{1}{2 \pi \lambda_{s}} \ln \frac{H}{\sqrt{3} r_{b}}
$$

Pretože sa teplota pozdĺž steny piloty zásadne mení, nie je ideálne používat' vzorec ktorý využíva teplotu v strede steny piloty. Doporučené je použitie integrálnej strednej teploty pozdíž piloty z čoho dostávame vzt’ah, získaný lineárnou regresiou, pre výpočet G-funkcie definovaný ako [5]:

$$
G(r)=\frac{1}{2 \pi \lambda_{s}} \ln \frac{H}{2,2 r_{b}}
$$

\section{POROVNANIE ANALYTICKÝCH MODELOV}

Porovnávané boli Inifinite line source model (4), Cylindrical source model (6) a Finite line source model (12),(13) s numerickým riešením. Prenos tepla bol modelovaný pomocou stacionárnych a dynamických simulácii. Analytické modely boli spočitané vo vlastnom výpočtovom programe, ktorý umožňuje stacionárny a nestacionárny výpočet výpočet výkonu q [W/m] pre pilotu lubovol'ného tvaru, pričom sú overené všetky vyššie spomínané podmienky výpočtu. Numerické riešenie bolo získané simuláciou v programe CalA 4 [6], tento program umožňuje stacionárny a nestacionárny výpočet vedenia tepla pomocu metódy kontrolných objemov na 2D ortogonálnej sieti, ktorú je možné riešit’ ako rotačne symetrickú. Vo všetkých simuláciach boli termofyzikálne vlastnosti materiálov považované za konštantné, izotropné a nezávislé na teplote. Schéma simulovanej piloty spolu s materiálovými vlastnost’amu a okrajovýmu podmienkami je možné vidiet' na Obr. 2a. Celkovo bolo simulovaných 100 dní prevádzky piloty, počas ktorých bolo nepretržite odoberané teplo zo zeminy. Časový krok pre analytické modely bol zvolený podl'a (3) na 96 hodín. Numerický model bol spočítaný v hodinovom kroku. Schéma numerického modelu a okrajových podmienok je možné vidiet' na Obr. 2b. Stacionárne výpočty boli spočítané pre čas získaný zo vzt’ahu (12) a pre Finite line source model pomocou Fourrierovho kritéria (13), pre tento model bola zist'ovaná len hodnota výkonu v ustálenom stave. 


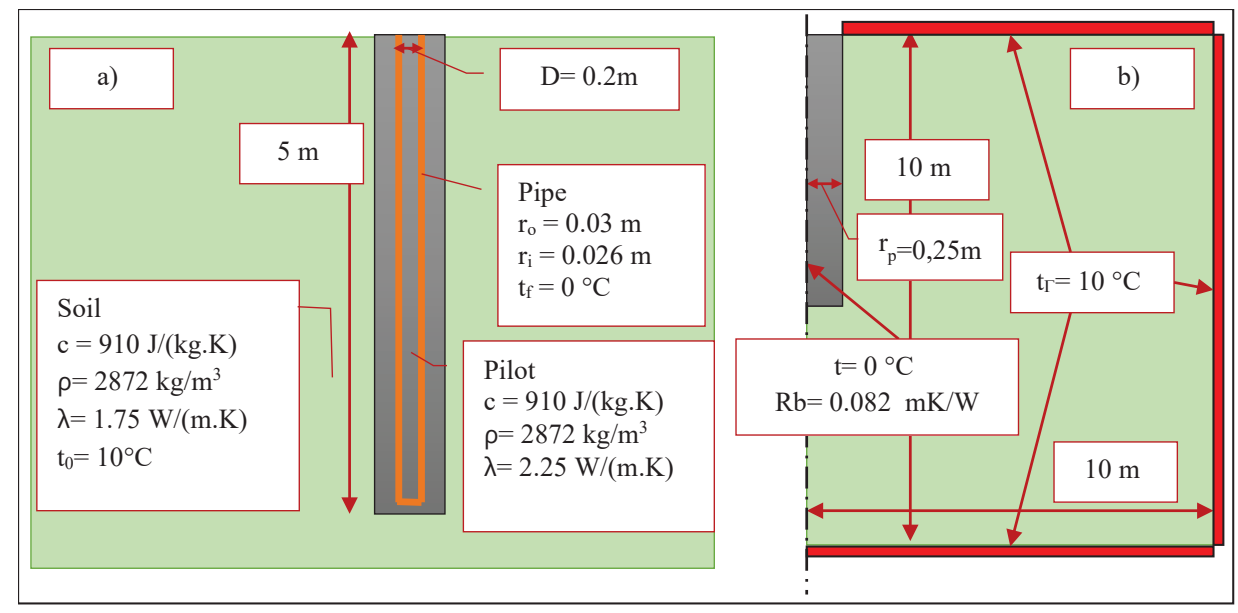

Obr.2 a) schema modelovaného prípadu, b) okrajové podmienky numerického modelu.

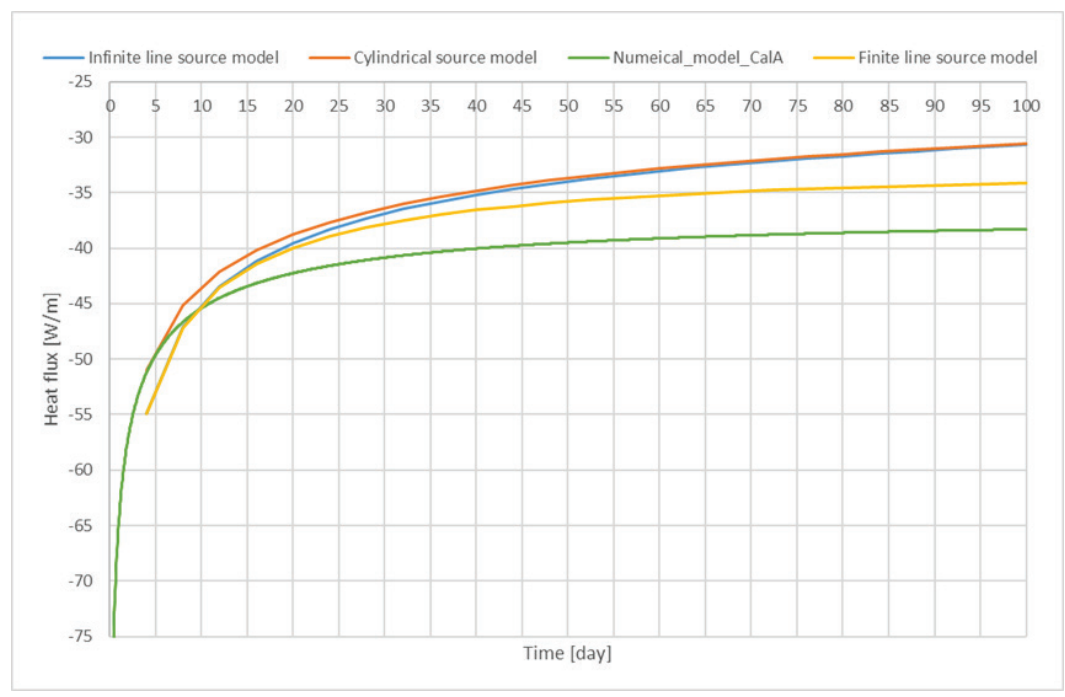

Obr. 3 Porovnanie tepelných tokov analytických modelov a numerických modelov.

Z výsledkov dynamických simulácii môžme pozorovat’ značný rozdiel v dosahovaných tepelných výkonoch. Najväčšie rozdiely medzi analytickým a numerickým výpočtom sú zaznamenané pri počiatočných časových krokoch, s postupujúcim časom sa rozdiely znižujú - Obr. 3. V tomto čase sú zaznamenané odlišnosti vo výkonoch až do takmer $30 \mathrm{~W} / \mathrm{m}$. Zo statických simulácií, ktoré udávajú výkon v ustálenom stave piloty, bola zistená relatívna chyba voči numerickému modelu ktorá sa pohybuje v rozsahu od $25 \%$ do $38 \%$.

Celkovo vykazuje najlepšiu zhodu z numerickým modelom Cylindrical source model, ale aj u tohto modelu je rozdiel vo výkone (25\%) stále pomerne vel'ký.

\section{ZÁVĚR}

Analytické modely, pôvodne navrhnuté na výpočet vrtov boli aplikované na tepelne aktivované piloty, z dosiahnutých výsledkov môžeme vidiet' pomerne vel'ké nepresnosti dosiahnutých výsledkov v porovnaní s numerickým modelom. Medzi hlavné nevýhody týchto modelov (IFLSM,CSM) patrí, že vo výpočte nezohl'adňujú vplyv pôsobenia povrchu zeme, čo je u pilot ktoré sú obecne kratšie ako vrty zásadné. Tento problém čiastočne rieši FLSM rozdelením na polopriestor, ale ani u neho nie je možné nastavit' rozdielnu okrajovú 
podmienku pre povrch zeminy a samotnú zeminu. Tieto modely majú, kvôli rozdielnej geometrii piloty oproti vrtu, väčšie obmedzenia minimálneho časového kroku (8) - rádovo v dňoch. A obdobne aj celkového výpočtového času (10), ktorý je kratší ako u vrtov.

Tieto analytické modely sú obecne vhodné, ked' potrebujeme rýchlo s malou výpočtovou náročnost'ou určit' približný výkon pilot. Pre fyzikálne podrobné riešenie sú vhodnejšie numerické modely. Do budúcna by bolo vhodné navrhnút' analytický model ktorý dokáže vyriešit' vyššie spomenuté nedostatky.

\section{Poděkování}

Příspěvek vznikl s podporou projektu FAST-J-21-7438 Optimalizace tepelně-aktivovaných konstrukcí pomocí algoritmů strojového učení.

\section{Použité zdroje}

[1] Ingersoll LR. Heat Conduction - With Engineering and Geological Application. DODO Press; 2007.

[2] CARSLAW, H.S. and J.C. JAEGER. Conduction of heat in solids. 2nd ed. Oxford: Claremore Press, 1959.

[3] LI, Min and Alvin C.K. LAI. Review of analytical models for heat transfer by vertical ground heat exchangers (GHEs): A perspective of time and space scales. Applied Energy. 2015, 151, 178-191. DOI: 10.1016/j.apenergy.2015.04.070. ISSN 03062619.

[4] Gu Y, O'Neal DL. Development of an equivalent diameter expression for vertical U-tubes used in ground-coupled heat pumps. ASHRAE Transactions, vol. 104, Texas A\&M Univ, College Station, US: 1998 , pp. 347-355.

[5] Zeng HY, Diao NR, Fang ZH. A finite line-source model for boreholes in geothermal heat exchangers. Heat Transfer - Asian Research 2002;31:558-567. doi:10.1002/htj.10057.

[6] Sikula O, Plasek J. Software CalA 4.0 (Calculation Area). version 4.0 Edu. 2015/10/05. doi:10.13140/RG.2.1.1501.7689. 